\title{
Optical properties of the waters of the southern Gulf of Mexico during summer
}

\author{
Erik Coria-Monter ${ }^{1}$, David Alberto Salas de León ${ }^{2}$ \\ María Adela Monreal-Gómez ${ }^{2}$ \& Elizabeth Durán-Campos ${ }^{3}$ \\ ${ }^{1}$ Cátedras CONACYT, Instituto de Ciencias del Mar y Limnología \\ Universidad Nacional Autónoma de México, Ciudad de México, México \\ ${ }^{2}$ Unidad Académica de Ecología y Biodiversidad Acuática, Instituto de Ciencias del Mar y Limnología \\ Universidad Nacional Autónoma de México, Ciudad de México, México \\ ${ }^{3}$ Unidad Académica Mazatlán, Instituto de Ciencias del Mar y Limnología \\ Universidad Nacional Autónoma de México, Ciudad de México, México \\ Corresponding autor: Erik Coria-Monter (coria@cmarl.unam.mx)
}

\begin{abstract}
The optical properties of the water column have a significant influence on phytoplankton growth. In this work, we report selected optical property values of the waters of two regions in the southern Gulf of Mexico. Measurements of natural fluorescence and photosynthetically available radiation (PAR) were made during a multidisciplinary research cruise, enabling the subsequent calculation of the light extinction coefficient $(k)$, compensation depth $\left(Z_{c}\right)$, critical depth $\left(Z_{c r}\right)$, and compensation light intensity $\left(E_{c}\right)$. The results revealed an interesting contrast between the two areas but also indicated the presence of optimal conditions for phytoplankton community growth and net primary production. These data, as reported here, could set the stage for the development of bio-optical models of light penetration, ocean color and primary productivity in the region, as well as for future analyses of organic carbon energy flow. However, many more studies are required to establish the possible seasonal variations in these parameters, which could be linked to the wide variability of the region.
\end{abstract}

Keywords: optical properties; chlorophyll- $a$; Campeche Canyon; Campeche Bank; Gulf of Mexico

The Gulf of Mexico (GM) is a semi-enclosed sea with variable topography, supporting a diverse marine community that includes high biomass of fish, seabirds and marine mammals. Given this biological importance, the gulf is recognized as one of the 64 Large Marine Ecosystems (LMEs) of the world (Sherman \& Hempel, 2009).

Two important features characterize the southern portion of the GM: the Campeche Canyon, an outstanding continental slope feature with a depth ranging from 160 to 2,800 m, and the Campeche Bank, a gently inclined, carbonate-dominated shelf extending 100 to $300 \mathrm{~km}$ from the coast and whose depth ranges from 200 to $300 \mathrm{~m}$ (Fig. 1a). Ocean dynamics and biological productivity in the region have received particular attention in recent years (Salas de León et al., 2004; Díaz-Flores et al., 2017; Durán-Campos et al., 2017; Salas-Monreal et al., 2018). Surface and subsur- face circulation is characterized by the presence of an anticyclonic-cyclonic eddy dipole (Salas de León $e t$ al., 2004), the occurrence of fronts over the Campeche Canyon (Aldeco-Ramírez et al., 2009) and a permanent cyclonic circulation over the Campeche Bay, delimited by the topography of the region (Díaz-Flores et al., 2017). These processes, in turn, support the high biological productivity of the southern GM, particularly that of phytoplankton.

Phytoplankton is the primary source of the marine food chain, not only contributing to major fishery resources around the world, but also playing a pivotal role in the marine ecosystem due to their contribution in mitigating climate change and global warming by reducing global $\mathrm{CO}_{2}$ levels (Vajravelu et al., 2017). Although phytoplankton ecology in the southern GM has been relatively well addressed in previous years (Signoret et al., 2006a; Linacre et al., 2015; Durán- 


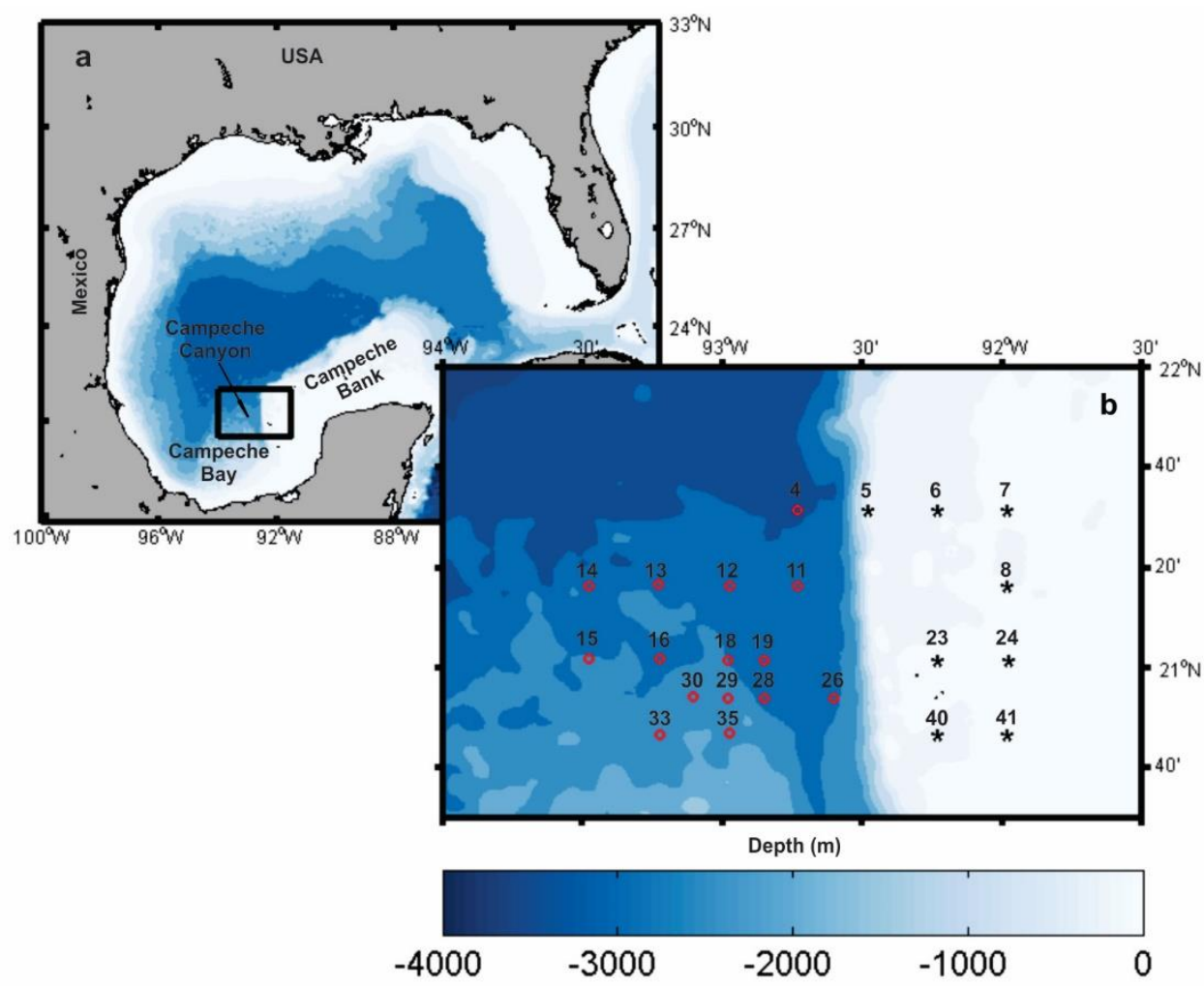

Figure 1. Study area: a) Gulf of Mexico, with the sampling area represented by a rectangle, b) stations with PNF-300 casts, with those over the Campeche Canyon represented by red circles, and those over the Campeche Bank represented by black stars. Bathymetry is shown in $\mathrm{m}$.

Campos et al., 2017), there have been major recent developments in this field, particularly regarding the optical properties of the water column because little in situ data have been available. The penetration of solar ultraviolet radiation and photosynthetically available radiation (PAR) into the ocean waters strongly depends on wavelength, which potentially affects the photophysiology and community composition phytoplankton because of the changes in the underwater light field (Piazena et al., 2002). Then, these properties are essential for phytoplankton growth and play a key role in models of light transmission, with light absorption in phytoplankton cells also driving photoautotrophic production in the ocean, and are also crucial for satellite ocean-color productivity (Takao et al., 2014). Additionally, the optical properties of the water column exert a major influence on the entire planktonic ecosystem by controlling the biological radiation exposure and the availability of solar energy for photosynthesis.

In this research it is reported, based on in situ observations, selected optical properties of the water column in two contrasting areas of the southern GM: Campeche Canyon and Bank. For this purpose, the information was collected during the multidisciplinary research cruise "PROMEBIO-VI," carried out from 12 to 17 June 2002 on board the R/V "Justo Sierra" of the Universidad Nacional Autónoma de México. Natural fluorescence, PAR and temperature were measured at 23 stations covering both the Campeche Canyon and Bank (Fig. 1b), using a PNF-300 profiler from Biospherical Instruments, previously calibrated by the manufacturer. This instrument measures the flux in natural fluorescence, which can then be used to estimate the instantaneous gross photosynthetic rate, while measurements of upwelling radiance $\left(\mathrm{L}_{u}(c h l), \mathrm{nE}\right.$ $\left.\mathrm{m}^{-2} \mathrm{~s}^{-1} \mathrm{str}^{-1}\right)$ are made by an optical sensor specifically over the emission spectrum of chlorophyll- $a$ (Chamberlin et al., 1990). Based on this approach, the calculation of chlorophyll concentration can be achieved via the simultaneous measurement of two optical variables: 1) the incident irradiance (which drives photosynthesis) and 2) the upwelling red radiance, which results from the fluorescence of the phytoplankton crop. PAR is measured over the spectral region from 400 to $700 \mathrm{~nm}$ using sensors with a flat quantum response (i.e., responding equally to all wavelengths). Thus, the chlorophyll- $a$ concentration $\left(\mathrm{mg} \mathrm{m}^{-3}\right)$ can be calculated from the natural fluores- 
cence flux $\left(F_{f}\right)$ and the incident irradiance using the following expression:

$$
\text { Chla }=\frac{F_{f}}{{ }_{{ }^{c}}(P A R) * \emptyset_{f} * E_{0}(P A R)}
$$

The above equation contains two important optical assumptions: ${ }^{\circ} a_{c}(P A R)$ is the chlorophyll-specific absorption coefficient (absorption normalized to chlorophyll concentration), and $\emptyset_{f}$ is the quantum fluorescence yield. These values were treated here as constants, such as in the software for the PNF-300, which assigned typical values of $0.04 \mathrm{~m}^{2} \mathrm{mg}^{-1}$ and $0.045 \mu \mathrm{E}$ fluoresced per $\mu \mathrm{E}$ absorbed, respectively. Fluorescence was transformed to chlorophyll- $a$ concentration $\left(\mathrm{mg} \mathrm{m}^{-3}\right)$ using equation 1 and was then integrated along the water column $\left(\mathrm{mg} \mathrm{m}^{-2}\right)$ following the expression (Signoret et al., 2006b):

$$
\operatorname{Chla}\left(\mathrm{mg} \mathrm{m}^{-2}\right)=\sum_{i=1}^{N}(\text { Chla }) i
$$

where Chla $\left(\mathrm{mg} \mathrm{m}^{-2}\right)$ is the chlorophyll- $a$ values vertically integrated, and $N$ is the last differential of the profile and corresponds to the depth of integration.

Based on the obtained PNF-300 measurements, we estimated the average light extinction coefficient in the water column $(k)$ according to Lalli \& Parsons (2006) and Falkowski \& Raven (2007) as:

$$
k=\frac{\ln \left(E_{0}\right)-\ln \left(E_{D}\right)}{z}
$$

where $E_{0}$ is surface radiation and $E_{D}$ is radiation at depth $z$. Here, it was used the Lalli \& Parsons' criterion (2006) who define $z$ as the limit of the euphotic zone.

The compensation depth $\left(Z_{c}\right)$, defined as the depth at which gross photosynthetic carbon fixation balances phytoplankton respiratory losses over one day, representing the lower boundary of the euphotic zone (Falkowski \& Raven, 2007), was calculated via the expression:

$$
Z_{c}=\frac{\ln \left(E_{0}\right)-\ln \left(E_{c}\right)}{k}
$$

where surface radiation $\left(E_{0}\right)$ is measured directly by the equipment, and $k$ is calculated using equation 3 , assuming a wavelength of $550 \mathrm{~nm}$ according to Lalli \& Parsons (2006). $E_{c}$ is the compensation light intensity, which varies with different species of phytoplankton as well as with the previous history of light adaptation of any particular species. For example, heavily shaded phytoplankton can adapt to lower light compensation intensities; in general, values of $E_{c}$ range between 1 and $10 \mu \mathrm{mol} \mathrm{m} \mathrm{m}^{-2} \mathrm{~s}^{-1}$ (Lalli \& Parsons, 2006). In this particular case, we used a constant value of $5 \mu \mathrm{mol} \mathrm{m}^{-2}$ $\mathrm{s}^{-1}$ according to the criterion of Nelson \& Smith (1991, and reference therein) and Signoret et al. (2006a), for the case of waters, such as the Gulf of Mexico.
The critical depth $\left(Z_{c r}\right)$, defined as the depth at which the water column's integrated photosynthesis is equal to the integrated respiration, was calculated via the expression:

$$
Z_{c r}=\frac{0.5 E_{0}}{E_{c} k}
$$

where $E_{0}$ is the incident irradiance (according to the criterion of Salas de León et al. (2004) and Signoret et al. (2006a), here multiplied by 0.5 based on $50 \%$ photosynthetic active radiance), $E_{c}$ is the irradiance at the depth at which gross photosynthesis is equal to respiration and $k$ is the extinction coefficient.

Finally, based on the vertical distribution of temperature, the mixed layer depth was estimated by the depth of the maximum temperature gradient $(\delta T / \delta z)$.

The calculation results revealed an interesting contrast between the two analyzed areas. Table 1 summarizes the results for the stations located at the Campeche Bank, and Table 2 the results for those located at the Campeche Canyon.

In order to visualize the vertical distribution pattern of temperature, chlorophyll- $a$ and PAR values, Fig. 2 shows a vertical profile representative for each region analyzed. This figure shows low chlorophyll- $a$ values in both zones $\left(<1 \mathrm{mg} \mathrm{m}^{-3}\right)$ with a peak close to the bottom for the station in the Campeche Bank (Fig. 2a) and a deep maximum (>60 $\mathrm{m}$ depth) in the station over the Campeche Canyon (Fig. 2b); in both areas, the peaks were located into the euphotic zone and below the thermocline. In Fig. 2a, it is also evident that, because of its shallowness, the whole water column is well lit, and levels of $1 \%$ of the incident surface radiation are not reached.

At the stations located along Campeche Bank, the deep chlorophyll maximum layer ranged from 0.20 to $0.80 \mathrm{mg} \mathrm{m}^{-3}$ and occurred close to the bottom. In contrast, at the Campeche Canyon stations, the maximum layer ranged more widely from 0.15 to 0.51 $\mathrm{mg} \mathrm{m}^{-3}$ and occurred at 46 to $76 \mathrm{~m}$ depth. Irradiance levels in the latter layer varied from 3.7 to $1 \%$, corresponding to the limit of the euphotic zone where net photosynthesis $>0$. These deep maxima of chlorophyll- $a$ layers in the Campeche Canyon have been associated with dominant phytoplankton species, including coccolithophores (Emiliana huxleyi, Gephyrocapsa oceanica, Florisphaera profunda), pennate diatoms (Nitzschia bicapitata, Nitzschia bifurcata), and dinoflagellates (Ceratium furca, Oxitoxum sp.) (Durán-Campos et al., 2017). The range of chlorophyll- $a$ values reported here, coincided with previous studies for the southern Gulf of Mexico during summertime. Using a PNF-300, Salas de León et al. 
Table 1. Optical properties of the water column at the Campeche Bank, the southern Gulf of Mexico, during summer.

\begin{tabular}{|c|c|c|c|c|c|c|c|c|}
\hline & St. 5 & St. 6 & St. 7 & St. 8 & St. 23 & St. 24 & St. 40 & St. 41 \\
\hline Latitude $\left({ }^{\circ} \mathrm{N}\right)$ & 21.50 & 21.50 & 21.49 & 21.24 & 21.00 & 21.00 & 20.75 & 20.75 \\
\hline Longitude $\left({ }^{\circ} \mathrm{W}\right)$ & 92.50 & 92.25 & 92.00 & 92.00 & 92.25 & 92.00 & 92.25 & 92.00 \\
\hline Profile time (GMT-6, h:min) & 11:39 & $13: 36$ & 16:01 & 18:06 & $06: 31$ & 09:18 & 14:00 & 05:54 \\
\hline Total depth (m) & 264 & 74 & 52 & 53.9 & 54 & 53 & 54 & 50 \\
\hline Euphotic layer thickness (m) & 90 & 70 & 50 & 50 & 54 & 53 & 50 & 49 \\
\hline Average extinction coefficient $(k)$ & 0.23 & 0.16 & 0.02 & 0.86 & 0.05 & 0.04 & 0.17 & 0.13 \\
\hline Incident irradiance $E_{0},\left(\mu \mathrm{mol} \mathrm{m}{ }^{-2} \mathrm{~s}^{-1}\right)$ & 272.4 & 175 & 152 & 131 & 188 & 378 & 94.97 & 215.51 \\
\hline Compensation depth, $Z c(\mathrm{~m})$ & 8.58 & 10.97 & 5.9 & 22.3 & 23.50 & 16.85 & 11.25 & 8.7 \\
\hline Critical depth $Z_{C r}(\mathrm{~m})$ & 9.54 & 13.64 & 32.27 & 46.21 & 32.30 & 53 & 12.83 & 9.2 \\
\hline Mixed layer (m) & 15 & 20 & 26 & 31 & 45 & 41 & 19 & 27 \\
\hline Integrated chlorophyll $\left(\mathrm{mg} \mathrm{m}^{-2}\right)$ & 2.7 & 1.7 & 4.1 & 3.3 & 4.4 & 4.6 & 4.3 & 7.5 \\
\hline Maximum chlorophyll depth (m) & 76 & 58 & 51 & 46 & 50 & 50 & 50 & 50 \\
\hline Chlorophyll at the maximum $\left(\mathrm{mg} \mathrm{m}^{-3}\right)$ & 0.20 & 0.40 & 0.60 & 0.27 & 0.40 & 0.80 & 0.54 & 0.50 \\
\hline Irradiance at chlorophyll maximum (\%) & 1.6 & 3.6 & 3.6 & 3 & 2.7 & 3.7 & 1.5 & 2 \\
\hline $\begin{array}{l}\text { Upwelling radiance }\left(\mathrm{L}_{\mathrm{u}}(\text { chla })\left(\mathrm{nE} \mathrm{m}^{-2} \mathrm{~s}^{-1} \mathrm{str}^{-1}\right) \text { at }\right. \\
\text { the chlorophyll maximum }\end{array}$ & 2.80 & 0.31 & 5.86 & 1.24 & 0.89 & 6.95 & 0.40 & 2.15 \\
\hline The temperature at the chlorophyll maximum $\left({ }^{\circ} \mathrm{C}\right)$ & 22 & 22 & 24 & 24 & 24 & 23 & 23 & 24 \\
\hline
\end{tabular}
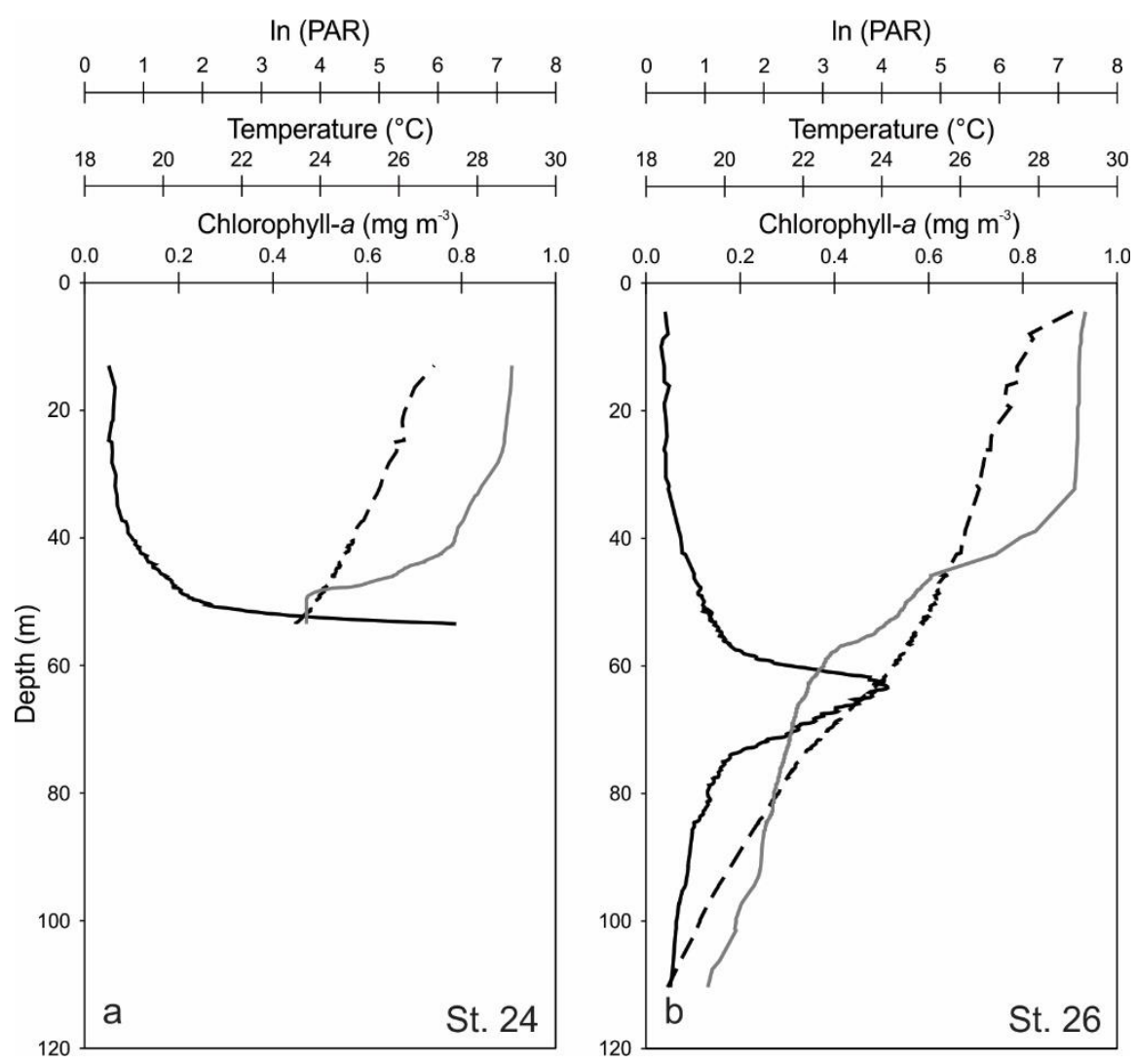

Figure 2. Vertical profiles of chlorophyll- $a\left(\mathrm{mg} \mathrm{m}^{-3}\right)$ (solid black line), temperature $\left({ }^{\circ} \mathrm{C}\right)$ (solid gray line) and PAR (black medium dash line) in a representative station at a) Campeche Bank and b) Campeche Canyon.

(2004) showed values ranging from 0.21 to $0.32 \mathrm{mg} \mathrm{m}^{-3}$ and maximum values of chlorophyll- $a$ vertically integrated of $13.3 \mathrm{mg} \mathrm{m}^{-2}$. Similarly, Signoret et al. (2006b) reported values from 0.02 to $0.45 \mathrm{mg} \mathrm{m}^{-3}$ and values of chlorophyll- $a$ vertically integrated from 1.7 to $12.7 \mathrm{mg} \mathrm{m}^{-2}$ during June. More recently, DuránCampos et al. (2017) revealed maximum values of 0.42 $\mathrm{mg} \mathrm{m}^{-3}$ at Campeche Canyon and $0.80 \mathrm{mg} \mathrm{m}^{-3}$ at Campe- 


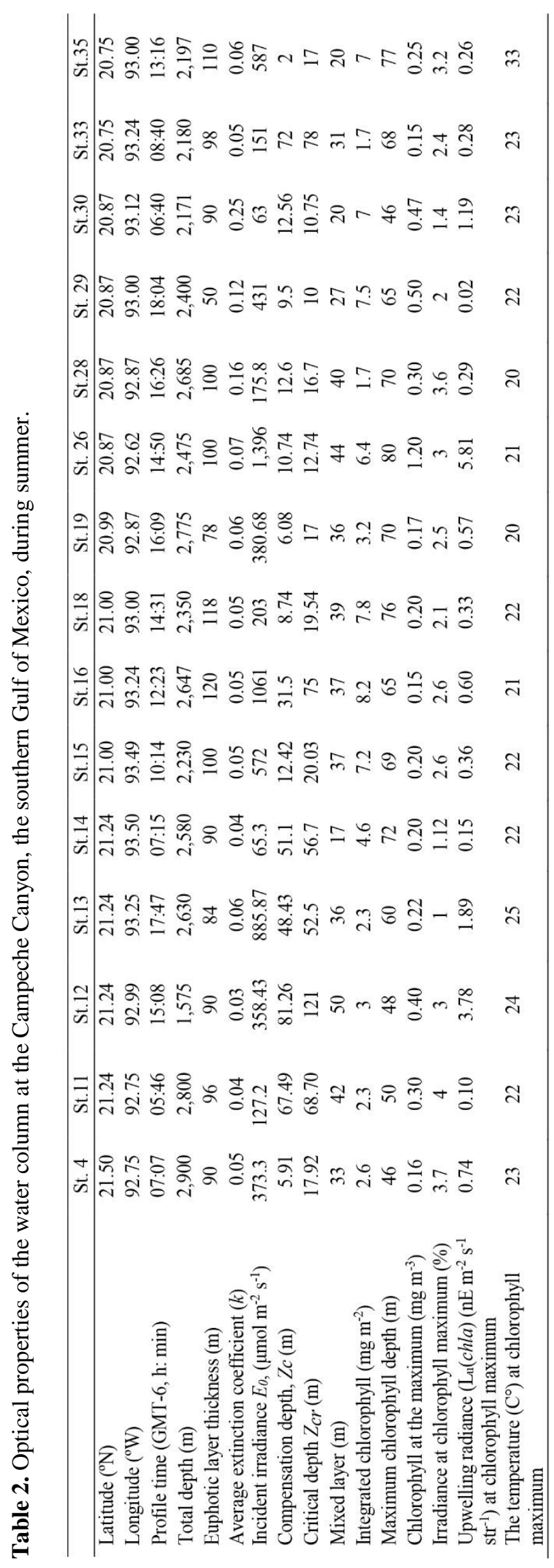

che Bank. Natural fluorescence measurements with a PNF-300 in the Sargasso Sea and South Pacific Ocean revealed values of chlorophyll- $a$ ranging from 0.03 to $0.60 \mathrm{mg} \mathrm{m}^{-3}$ and from 0.09 to $0.53 \mathrm{mg} \mathrm{m}^{-3}$, respectively (Chamberlin et al., 1990). However, these values are lower compared with other domains; for example, Coria-Monter et al. (2017) recorded values from 0.8 to $2.00 \mathrm{mg} \mathrm{m}^{-3}$ in the Bay of La Paz, southern Gulf of California, Mexico, using a PNF-300 as a method.

Our observations revealed values of incident irradiance $\left(E_{0}\right)$ ranging from 94.97 to $378 \mu \mathrm{mol} \mathrm{m}^{-2} \mathrm{~s}^{-1}$ in the stations located at Campeche Bank, whereas the station located at the Campeche Canyon rose into a range from 63 to $1396 \mu \mathrm{mol} \mathrm{m} \mathrm{m}^{-2} \mathrm{~s}^{-1}$. Although these values depend on the time of the day when measurements are made due to the sun angle, reaching values of $>1,000 \mu \mathrm{mol} \mathrm{m} \mathrm{m}^{-2} \mathrm{~s}^{-1}$ in a sunny day (Kirk, 2011), the values presented here are in agreement with those by Salas de León et al. (2004) who reported values for the southern Gulf of Mexico ranging from 84.6 to $695 \mu \mathrm{mol} \mathrm{m} \mathrm{m}^{-2}$.

Values of $k, Z_{c}$ and $Z_{c r}$ have a significant influence on phytoplankton crop growth. As $k$ varies according to wavelengths of light, values ranging from 0.035 to $0.140 \mathrm{~m}^{-1}$ have been reported by Lalli \& Parsons (2006), in agreement with our observations. According to Falwowski \& Raven (2007), values of $k$ could be potentially affected by the amount of chlorophyll contained in living phytoplankton and in plant debris. When $Z_{c}$ is shallower than $Z_{c r}$, the growth rate exceeds the vertical mixing rate, and hence phytoplankton can grow in the euphotic layer (Huisman et al., 1999). In both analyzed GM regions, conditions are optimal for phytoplankton growth and net primary production is likely, since $Z_{c r}$ was found to be higher than $Z_{c}$. Net primary production represents the organic carbon produced by photosynthesis processes within a specified time of ecological relevance, which is subsequently made available to other trophic levels (Falkowski \& Raven, 2007)

To date, very few studies have reported in situ measurements of water column optical properties in the southern portion of the GM; as a result, it is not yet possible to establish any seasonal variability in these parameters. Available data is currently limited to the work of Salas de León et al. (2004), who found similar results, particularly $k, E_{c}$ and $Z_{c r}$ values, in the Campeche Canyon during the summer of 1999. To date, it is well known that in spring $Z_{c}$ is generally increasing rapidly with the time, due to the effects of the increasing day length and solar elevation on $E_{0}$ (Nelson \& Smith, 1991). 
As $E_{c}$ is fundamental to phytoplankton growth, it has been widely calculated for other oceanic domains. Indeed, the application of Sverdrup's (1953) model of the conditions required for the spring bloom of phytoplankton requires knowledge of $E_{c}$ values. The latter author assumed value of $\approx 0.6 \mathrm{~mol} \mathrm{~m}^{-2} \mathrm{~d}^{-1}$ based on previous phytoplankton culture studies, and this value remains in use today. However, Riley (1957) suggested a value of $E_{c}$ of $3.5 \mathrm{~mol} \mathrm{~m}^{-2} \mathrm{~d}^{-1}$, while Siegel et al. (2002) reported $E_{c}$ values ranging from 0.96 to $1.75 \mathrm{~mol} \mathrm{~m}^{-2} \mathrm{~d}^{-1}$ in the North Atlantic.

Furthermore, due to the lack of in situ PAR measurements for the GM, especially its southern portion, it was not possible to make a comparison between seasons and between zones. As PAR plays an essential role in providing energy to support photosynthesis and other primary phytoplankton functions, its measurement is essential.

Nevertheless, the results reported here represent a first step in the potential development of bio-optical models of light penetration, ocean color and primary productivity in the region. The data could also be used for future analyses of organic carbon energy flow, as well as for those examining the interannual variability of heterotrophic processes such as the energy flow from autotrophs to heterotrophs.

Many more detailed in situ observations regarding the optical properties of the water column in the southern GM are required to establish the possible seasonal variation in these parameters, which are linked not only to circulation patterns but also to nutrient concentrations available to phytoplankton. Additional processes with a potentially strong influence on the optical properties of the region's water column include the strong winds that arise during winter, known as "nortes", which originate water mixing and the subsequent resuspension of particles and organic matter from the bottom.

\section{ACKNOWLEDGMENTS}

Consejo Nacional de Ciencia y Tecnología de México (CONACYT) sponsored E. Coria-Monter during this study. Ship time for the research cruise PROMEBIOVI on board the R/V Justo Sierra was funded by the Universidad Nacional Autónoma de México (UNAM). The authors would like to thank all the participants of the research cruise, including the captain and crew. F. Sergio Castillo-Sandoval provided technical support during the analyses. Many helpful comments by two anonymous reviewers enabled us to improve the manuscript greatly.

\section{REFERENCES}

Aldeco-Ramírez, J., Monreal-Gómez, M.A., Signoret, M., Salas de León, D.A. \& Hernández-Becerril, D.U. 2009. Occurrence of a subsurface anticyclonic eddy, fronts, and Trichodesmium spp. over the Campeche Canyon region, Gulf of Mexico. Ciencias Marinas, 35(4): 333-344.

Chamberlin, W.S., Booth, C.R., Kiefer, D.A., Morrow, J.H. \& Murphy, R.C. 1990. Evidence for a simple relationship between natural fluorescence, photosynthesis, and chlorophyll in the sea. Deep-Sea Research Part A, 37: 951-973.

Coria-Monter, E., Monreal-Gómez, M.A., Salas de León, D.A. \& Durán-Campos, E. 2017. Wind driven nutrient and subsurface chlorophyll- $a$ enhancement in the Bay of La Paz, Gulf of California. Estuarine, Coastal and Shelf Science, 196: 290-300.

Díaz-Flores, M.A., Salas de León, D.A. \& MonrealGómez, M.A. 2017. Origin and evolution of cyclonic eddy of the bay of Campeche, Gulf of Mexico. Revista de Biología Marina y Oceanografía, 52(3): 441-450.

Durán-Campos, E., Salas de León, D.A., Monreal-Gómez, M.A. \& Coria-Monter, E. 2017. Patterns of chlorophyll$a$ distribution linked to mesoscale structures in two contrasting areas Campeche Canyon and Bank, Southern Gulf of Mexico. Journal of Sea Research, 123: 30-38.

Falkowski, P.G. \& Raven, A. 2007 Aquatic photosynthesis. Princeton University Press, New Jersey.

Huisman, J., Van Oostveen, P. \& Weissing, F.J. 1999. Critical depth and critical turbulence: two different mechanisms for the development of phytoplankton blooms. Limnology and Oceanography, 44(7): 17811787.

Kirk, J.T.O. 2011. Light and photosynthesis in aquatic ecosystems. Cambridge University Press, New York.

Lalli, C.M. \& Parsons, T.R. 2006. Biological oceanography, an introduction. Butterworth-Heinemann, Oxford.

Linacre, L., Lara-Lara, R., Camacho-Ibar, V., Herguera, J.C., Bazán-Guzmán, C. \& Ferreira-Bartrina, V. 2015. Distribution pattern of picoplankton carbon biomass linked to mesoscale dynamics in the southern Gulf of Mexico during winter conditions. Deep-Sea Research Part I, 106: 55-67.

Nelson, D.M. \& Smith, W.O. 1991. Sverdrup revisited: critical depths, maximum chlorophyll levels, and the control of Southern Ocean productivity by the irradiance-mixing regime. Limnology and Oceanography, 36(8): 1650-1661.

Piazena, H., Perez-Rodrigues, E., Hader, D.P. \& LopezFigueroa, F. 2002. Penetration of solar radiation into the water column of the central subtropical Atlantic Ocean - optical properties and possible biological 
consequences. Deep-Sea Research Part II, 49: 35133528.

Riley, G.A. 1957. Phytoplankton of the North Central Sargasso Sea, 1950-1952. Limnology and Oceanography, 2(3): 252-270.

Salas de León, D.A., Monreal-Gómez, M.A., Signoret, M. \& Aldeco-Ramírez, J. 2004. Anticyclonic-cyclonic eddies and their impact on near-surface chlorophyll stocks and oxygen supersaturation over the Campeche Canyon, Gulf of Mexico. Journal of Geophysical Research, 109: C05012.

Salas-Monreal, D., Marín-Hernández, M., Salas-Pérez, J.J., Salas de León, D.A., Monreal-Gómez, M.A. \& Pérez-España, H. 2018. Coral reef connectivity within the western Gulf of Mexico. Journal of Marine Systems, 179: 88-99.

Sherman, K. \& Hempel, G. 2009. Perspectives on regional seas and the large marine ecosystem approach In: Sherman, K. \& Hempel, G. (Eds.). The UNEP large marine ecosystem report: a perspective on changing conditions in LMEs of the world's regional seas. UNEP Regional Seas Report and Studies 182. United Nations Environment Programme. Nairobi, Kenya.

Siegel, D.A., Doney, S.C. \& Yoder, J.A. 2002. The North Atlantic spring phytoplankton bloom and Sverdrup's critical depth hypothesis. Science, 296: 730-733.

Received: 11 July 2018; Accepted: 12 February 2019
Signoret, M., Monreal-Gómez, M.A., Aldeco, J. \& Salas de León, D.A. 2006a. Hydrography, oxygen saturation, suspended particulate matter, and chlorophyll$a$ fluorescence in an oceanic region under freshwater influence. Estuarine, Coastal and Shelf Science, 69: 153-164.

Signoret, M., Aldeco, J. \& Barreiro, M.T. 2006 b. Variability of chlorophyll $a$ profiles obtained by natural fluorescence in the west and center Gulf of Mexico in June 1999. Hidrobiológica, 16: 221-232.

Sverdrup, H.U. 1953. On conditions for the vernal blooming of phytoplankton. Journal du Conseil Permanent International pour l'Exploration de la Mer, 18: 287-295.

Takao, S., Iida, T., Isada, T., Saitoh, S.I., Hirata, T. \& Suzuki, K. 2014. Bio-optical properties during the summer season in the Sea of Okhotsk. Progress in Oceanography, 126: 233-241.

Vajravelu, M., Martin, Y., Ayyappan, S. \& Mayakrishnan, M. 2017. Seasonal influence of physic-chemical parameters on phytoplankton diversity, community structure, and abundance at Parangipettai coastal waters, Bay of Bengal, the southeast coast of India. Oceanologia, 60(2): 114-127. 